\title{
Physicochemical and Tissue Response of PLA Nanofiber Scaffolds Sterilized by Different Techniques
}

\section{Evaluación fisicoquímica y respuesta tisular de andamios nanofibrilares de PLA esterilizados por diferentes técnicas}

Isarai Mendieta-Barrañon DDS1; Osmar A. Chanes-Cuevas DDS, MSc'; Marco A. Álvarez-Pérez PhD1; Patricia González-Alva DDS, PhD1; Luis A. Medina PhD²,3;

Manuel Aguilar-Franco MSc²; Janeth Serrano-Bello DDS, MSc, PhD1

1. Laboratorio de Bioingeniería de Tejidos; DEPel, Facultad de Odontología, Universidad Nacional Autónoma de México, Circuito Exterior s/n. Cd. Universitaria, 04510 Coyoacán, CDMX, México.

2. Instituto de Física, Universidad Nacional Autónoma de México, Circuito Exterior s/n. Cd. Universitaria, 04510 Coyoacán, CDMX, México.

3. Unidad de Investigación Biomédica en Cáncer INCan/UNAM, Instituto Nacional de Cancerología, CDMX 14080, México.

Correspondence to: Dra. Janeth Serrano-Bello - janserbe@comunidad.unam.mx

Received: 14-X-2018

Accepted: 19-XI-2018

Published Online First: 26-XI-2018

DOI: 10.15517/IJDS.V0I0.35324

ABSTRACT

In recent years, tissue engineering has evolved considerably, due to the problems in the biomedical area concerning tissue regeneration therapies. Currently, work has been focused on the synthesis and physicochemical characterization of poly lactic acid scaffolds, a synthetic polyester that has been extensively study for its excellent biocompatibility and biodegradability. Moreover, sterilization strategies of scaffold are a crucial step for its application in tissue regeneration, however, the sterilization process have to maintain the structural and biochemical properties of the scaffold. Therefore, it is very important to carry out studies on the sterilization methods of the sample's material, since translational medicine is intended for in vivo applications. The aim of the present study was designed to analyze the effects of different sterilization techniques, i.e. ethylene oxide (ETO), gamma radiation (GR) and hydrogen peroxidebased plasma $\left(\mathrm{H}_{2} \mathrm{O}_{2}\right)$ in biodegradable PLA scaffolds, and to determine the best sterilization technique to render a sterile product with minimal degradation and deformation, and good tissue response. Analysis of surface morphology showed that ETO and GR modified the PLA scaffolds without any change in its chemical composition. Moreover, the histological response showed that the scaffolds are biocompatible and those sterilized by GR showed a more severe inflammatory response, accompanied with the presence of giant foreign body cells. In conclusion, the results show that among sterilization techniques used in the preset study, the best results were observed with $\mathrm{H}_{2} \mathrm{O}_{2}$ sterilization, since it did not significantly modify the surface structure of the PLA fibers and their in vivo response did not cause an unfavorable tissue reaction. 


\section{KEY WORDS}

Tissue engineering; PLA scaffolds; Sterilization techniques; Ethylene oxide; Gamma radiation; Hydrogen peroxide.

\section{RESUMEN}

En los últimos años, la ingeniería de tejidos ha evolucionado considerablemente, debido a las incógnitas en las terapias de regeneración en el área biomédica. Actualmente, se ha trabajado en la síntesis y caracterización fisicoquímica de andamios de poliácido láctico, el cual es un polímero sintético que se ha estudiado para aplicaciones en ingeniería de tejidos, debido a su biocompatibilidad y biodegradabilidad. El proceso de esterilización es un paso crucial en la aplicación de andamios en terapias de regeneración, sin embargo, la técnica de esterilización debe mantener las propiedades estructurales y bioquímicas del andamio. Por lo tanto, es muy importante realizar estudios sobre los métodos de esterilización de dichos andamios, ya que la medicina traslacional está diseñada para aplicaciones in vivo. El objetivo del presente estudio fue analizar los efectos de diferentes técnicas de esterilización como óxido de etileno (ETO), radiación gamma (GR) y plasma a base de peróxido de hidrógeno $\left(\mathrm{H}_{2} \mathrm{O}_{2}\right)$ en andamios biodegradables de PLA, y determinar la mejor técnica de esterilización con mínima degradación y deformación, así como una respuesta tisular favorable. La estructura de la superficie de los andamios de PLA se modificó principalmente con las técnicas de óxido de etileno y radiación gamma, sin embargo, ninguna técnica modificó su composición química. Con la respuesta histológica se demostró que los andamios de PLA son biocompatibles y que los esterilizados por radiación gamma desencadenan una mayor respuesta inflamatoria y la formación de células gigantes de cuerpo extraño. En conclusión, los resultados muestran que las técnicas de esterilización utilizadas pueden modificar la morfología del andamio, sin embargo; los mejores resultados se observaron con la esterilización por plasma a base de peróxido de hidrógeno, ya que no modificó significativamente la estructura de la superficie de las fibras de PLA y su respuesta in vivo no provocó una reacción desfavorable en el tejido.

\section{PALABRAS CLAVE}

Ingeniería de tejidos; Andamios de PLA; Técnicas de esterilización; Óxido de etileno; Radiación gama; Peróxido de hidrógeno.

\section{INTRODUCTION}

Tissue bioengineering seeks the combination of scaffolds, cells and biologically active molecules $(1-4)$, with the aim to restore or maintain the normal function of an organ or tissue (2,5-7). The regeneration is then achieved with a threedimensional construct (the scaffold), designed to support the infiltration of new cells, their growth and differentiation, and to enhance new tissue development. Therefore, the applications of tissue bioengineering in the field of medicine opens new alternatives for treating patients with different pathologies (8-10), such as trauma, fractures, reconstructive surgery, among others (11).

For bone defects regeneration, many biomaterials have been used to fabricate scaffolds, including metals, ceramics, glasses, and polymers. Also, many different types of grafts (autografts, 
xenografts and allografts) are used in the clinic, and to date the results are not completely predictable. Nowadays, biodegradable polymers for scaffolds and other implants for various tissue engineering applications is a common trend, and it has been extensively studied. A widely used synthetic polymer in the field of tissue engineering is the poly(lactic acid) (PLA) due to the physicochemical properties of the material, such as, mechanical and thermal properties, degradation characteristic, and also, it is relatively easy to manufacture (1215). However, due to the nature of their chemical properties, most polymeric biomaterials are sensitive to the conditions required by standard sterilization methods, since polymers are highly sensitive to heat, humidity and radiation. Therefore, infections associated with the in vivo use of the scaffolds by different microbial contaminants represent a constant challenge. So, when in vitro studies are carried out on translational research in experimental animals, a sterilization process is essential for every material or device used. Also, it is important to evaluate the method by which the biodegradable scaffolds manufactured in the laboratory can be effectively sterilized, and at the same time maintain their structural and biochemical properties. The purpose of this study was to evaluate changes in the physical and chemical properties of $7 \%(\mathrm{w} / \mathrm{v})$ of PLA nanofiber scaffolds after sterilization process by gamma irradiation (GR), ethylene oxide (ETO) and hydrogen peroxide plasma $\left(\mathrm{H}_{2} \mathrm{O}_{2}\right)$ and with the consequent evaluation of tissue response after scaffold sterilization.

\section{MATERIALS AND METHODS}

\section{PREPARATION OF PLA SCAFFOLDS BY AIR JET SPINNING}

Scaffolds were prepare as previously described (16). Briefly, 7\% wt of PLA pellets (C3H603; MW 192,000; Nature Works, MN, USA) were dissolved in chloroform $\left(\mathrm{CHCl}_{3}\right)$, and stirred for $20 \mathrm{~h}$. Subsequently anhydrous absolute ethyl alcohol $\left(\mathrm{CH}_{3} \mathrm{CH}_{2} \mathrm{OH}\right.$, J.T. Baker Inc., USA) was added and the solution was further stirred for 30 min until a homogeneous solution was achieved. The volume ratio of chloroform/ethanol was 3:1.

The polymeric PLA 7\% solution was placed in a commercial ADIR (model 699) airbrush with $0.3 \mathrm{~mm}$ nozzle diameter and with gravitational feed of the solution to synthesize a fiber membrane scaffold over a sheet of wax paper. The airbrush was connected to a pressurized argon tank (30 $\mathrm{psi})$, and the distance between the nozzle and the wax paper was set at a constant of $15 \mathrm{~cm}$.

The sheets of $7 \%$ of PLA nanofiber scaffold were cut into round of $9 \mathrm{~mm}$ of diameter, and then sterilized with different procedures.

\section{STERILIZATION OF PLA SCAFFOLDS WITH GAMMA RAYS (GR)}

The PLA nanofiber scaffolds were stored in self-seal plastic bags. Samples were placed in a Gamma beam 651PT irradiation chamber, and Gamma-irradiation sterilization was achieved at a dose of $25 \mathrm{kGy} 60 \mathrm{Co}$ at room temperature in the dark.

\section{STERILIZATION OF PLA SCAFFOLDS WITH ETHYLENE OXIDE (ETO)}

Nanofiber scaffolds were placed in packed self-seal sterilization pouches (PMG $\circledR$ medical grade). Ethylene oxide sterilization was achieved in a 100\% ET0 atmosphere at 370 C for $5 \mathrm{~h}$, followed by a second cycle of $370 \mathrm{C}$ for $5 \mathrm{~h}$. Finally, the scaffolds were aerated for $12 \mathrm{~h}$ to eliminate the gas retained.

\section{STERILIZATION BY HYDROGEN PEROXIDE-BASED PLASMA ( $\left.\mathrm{H}_{2} \mathrm{O}_{2}\right)$}

Nanofiber scaffolds were packed in sterilization pouches (Tyvek® bags) for treatment 
by $\mathrm{H}_{2} \mathrm{O}_{2}$ based plasma in an equipment (STERRAD $\AA$ 100NX System). The sterilization procedure was carried out with a cycle of 54 minutes, at a temperature of $50^{\circ} \mathrm{C}$.

EVALUATION OF PLA NANOFIBER SCAFFOLDS BY SCANNING ELECTRON MICROSCOPY (SEM)

The morphology of the nanofiber scaffold was evaluated by SEM microscope (JEOL JSM 5600) to evaluate if the different sterilization methods could modify the surface structure of the scaffolds. The polymer disk scaffolds were attached to aluminum stubs with double-side sticky tabs before being coated with gold using a sc500 (EMScope) sputter coater. The scaffolds were photographed and then analyzed with Image ${ }^{\circledR}$ software. The diameter of the fibers was counted, and the data and the graphs were made and analyzed in the Origin $\circledast$ program. All scaffolds were used with no more than a week after sterilization procedures.

\section{EVALUATION OF PLA SCAFFOLDS BY ATR-FTIR}

To evaluate modification of the chemical composition of PLA scaffolds due to the different sterilization techniques used, spectra were obtained by reflectance spectroscopy technique (ATRFTIR). The resolution of the spectra was $4 \mathrm{~cm}-1$ with a total of 64 scans. The area of attenuated total reflectance was $2 \mathrm{~mm}$ in diameter and the penetration of the radiation was about $2 \mu \mathrm{m}$.

\section{IN VIVO TISSUE RESPONSE}

The in vivo section of the present study was approved by the local ethics committee at the Faculty of Dentistry of the National Autonomous University of Mexico (UNAM), project number CIE/10/01/2015. A total of fifteen male Wistar rats of $250 \mathrm{~g}$ were used. The animals were housed at a constant temperature of $24^{\circ} \mathrm{C}$, with a $12 \mathrm{~h}$ light to $12 \mathrm{~h}$ dark rotation. They were fed standard pellets for rodents (rodent diet 5001) and water from a controlled water source.

\section{SURGICAL PROCEDURE}

Each animal was sedated with a mixture of Ketamine $(80 \mathrm{mg} / \mathrm{kg})$ and Xylazine $(10 \mathrm{mg} / \mathrm{kg})$ intramuscularly. When fully sedated the animal was moved to the dissection table and the dorsum of the rat was shaved and cleaned with antiseptics. Subsequently, the dorsum was divided into quadrants and a $2 \mathrm{~cm}$ linear incision was made to form a triangular flap. The sterilized scaffolds and the control were place as showed in figure 1. Briefly, in the upper right corner of the incised area the sterilized samples with ETO, in the upper left those sterilized with $\mathrm{H}_{2} \mathrm{O}_{2}$, in the lower right the samples sterilized with GR, and finally in the lower left a control sample was only disinfected with $70 \%$ ethanol. All samples were sutured with 5-0 Nylon and placed as far as possible from the incision.

\section{IN VIVO SAMPLE PREPARATION}

The animals were checked postoperative, to evaluate their general condition every day until sacrifice with an overdose of $\mathrm{CO}_{2}$ at 4 , 10 or 21 days. Five samples from each group were retrieved at each time point. At the end of the established times (4, 10 and 21 days), the area where the scaffolds were placed was cut with a safety margin of $2 \mathrm{~mm}$, the samples were put in 10\% formalin for 24 hours. Finally, they were processed and embedded in paraffin. Serial sections of $5 \mu \mathrm{m}$ thickness from the paraffin blocks were stained with Hematoxylin and Eosin for evaluation under optical microscopy.

\section{STATISTICAL ANALYSIS}

All statistical tests were performed using SPSS IBM software (version 20.0). Differences in mean values between groups were analyzed 
with the ANOVA test. A $p$ value of $<0.05$ was considered significant.

\section{RESULTS}

SURFACE STRUCTURE EVALUATION OF PLA SCAFFOLDS BY SEM

SEM was used to quantify the average size and distribution of three-dimensional PLA scaffolds after each sterilization technique, and compare with non-sterilized scaffolds. SEM images revealed that sterilization methods affect the random distribution of the polymer nanofibers. Non-sterilized scaffolds showed an average fiber diameter of $0.670 \pm 0.08 \mu \mathrm{m}$. However, sterilized scaffolds by means of GR showed that the diameter of the nanofibers decreased $(0.500 \pm 0.07 \mu \mathrm{m})$, also, ETO and $\mathrm{H}_{2} \mathrm{O}_{2}$ sterilized scaffolds showed a similar decreased on the average fiber diameter $(0.610$ and $0.650 \pm 0.1 \mu \mathrm{m}$, respectively). The only group that presented statistical differences against the control was GR sterilized scaffolds with a $p<0.05$.

\section{EVALUATION OF PLA SCAFFOLDS BY FTIR}

The chemical identity of the nanofiber scaffold was analyzed by FTIR-ATR (Figure 4). The spectra showed the typical resonance for PLA scaffold and no significant changes were observed among the groups studied. The $\mathrm{CH}_{3}$ group resonance was manifested as peak at $2925 \mathrm{~cm}-1$ and $1274 \mathrm{~cm}-$ 1. The $\mathrm{C}=0$ group resonance was observed at $1756 \mathrm{~cm}-1$ and carboxyl group was detected at $1090 \mathrm{~cm}-1$, which are the same for all conditions.

HISTOLOGICAL EVALUATION IN SUBCUTANEOUS TISSUE IN WISTAR RATS

Figure 5 shows histological sections of subcutaneous cell tissue from Wistar rats at different post-implantation days (4, 10 and 21) of PLA scaffolds sterilized by different methods. Briefly, the histological sections corresponding to the 4 days after surgery showed a fibrillar material in the area were the scaffold was implanted, and in all the conditions used (control, GR, ETO and $\mathrm{H}_{2} \mathrm{O}_{2}$ ). The fibrillar material was surrounded by a connective tissue capsule, with scarce lymphocytic inflammatory infiltrate.

By day 10 the presence of the fibrillar material was still observed, however, the fibers were more evident in the control group, and in samples sterilized by $\mathrm{H}_{2} \mathrm{O}_{2}$. As for the connective tissue capsule, a moderate inflammatory infiltrated was present in the control group and samples sterilized by ETO. This infiltrated was composed by polymorphonuclear lymphocytes, macrophages and some giant cells. However, the samples sterilized with gamma radiation and $\mathrm{H}_{2} \mathrm{O}_{2}$ showed only a scarce inflammatory infiltrated, where giant cells are not present. It should be noted that for the samples sterilized by $\mathrm{H}_{2} \mathrm{O}_{2}$, the connective tissue capsule surrounding the material was smaller in diameter compared to capsules of scaffolds sterilized with ETO or GR.

The samples from the 21 days showed the presence of the fibrillar material in the control group, and also, in samples sterilized with ETO and GR. In all samples sterilized with ETO or GR, giant cells were around the connective tissue capsule, along with a lymphocytic inflammatory infiltrate and thickening of the fibrous capsule. As for the samples sterilized by $\mathrm{H}_{2} \mathrm{O}_{2}$ the reaction around the scaffold tends to be more circumscribed and less intense. Also, giant cells were absent, and the connective tissue capsule was thinner in the samples of the scaffolds sterilized with $\mathrm{H}_{2} \mathrm{O}_{2}$, compare with the samples from scaffolds sterilized with ETO and GR. 

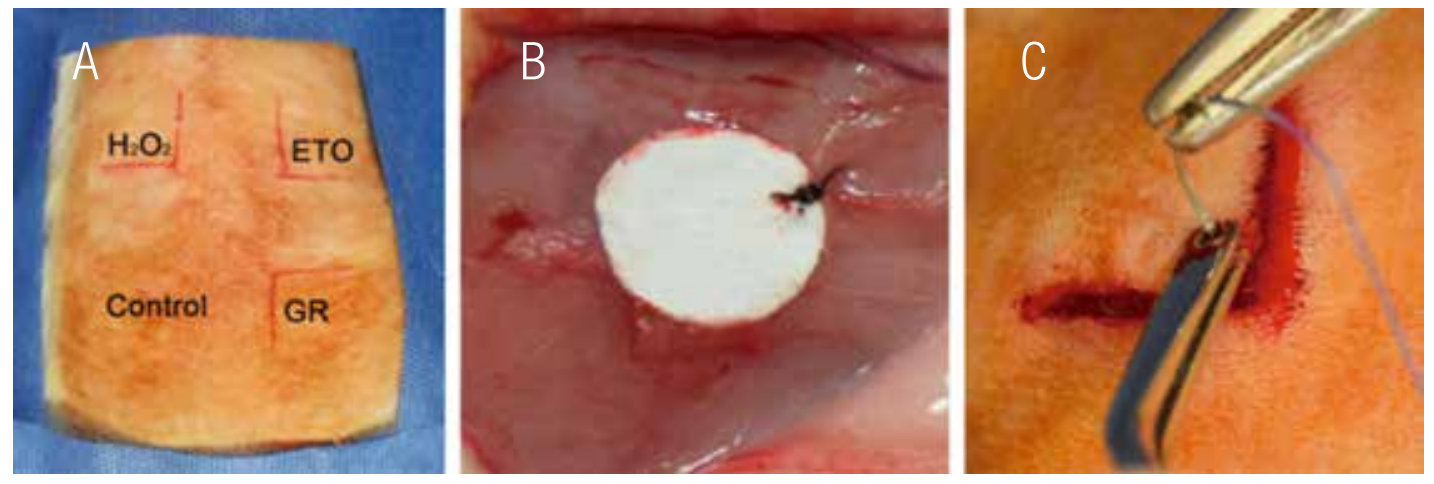

Figure 1. Surgical procedure. A) distribution of the samples in the Wistar rat back. B) Suture of the sample in subcutaneous tissue with Nylon 5-0. C) Flap is sutured with 3-0 Vicryl.
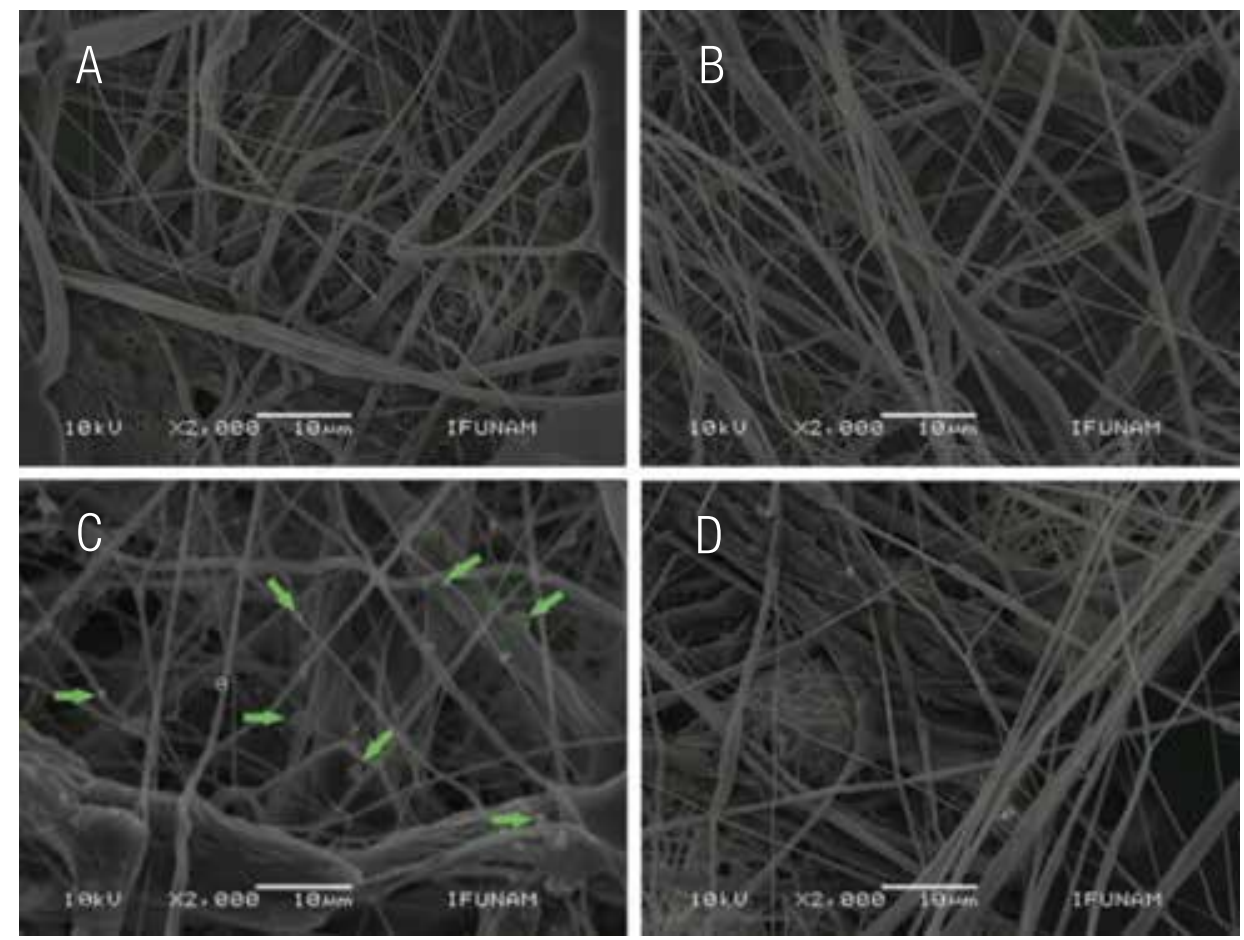

Figure 2. Photomicrography of Scanning Electron Microscopy of the surfaces of the PLA scaffolds, with the different conditions. A) Control scaffolding disinfected, B) Scaffold sterilized by means of GR, C) ETO where the presence of clusters in scaffold fibers (arrows) and D) scaffold sterilized with $\mathrm{H}_{2} \mathrm{O}_{2}$. $\mathrm{GR}=\mathrm{Gama}$ radiation, ETO $=$ Ethylene Oxide, $\mathrm{H}_{2} \mathrm{O}_{2}=$ Hydrogen Peroxide Based Plasma. 


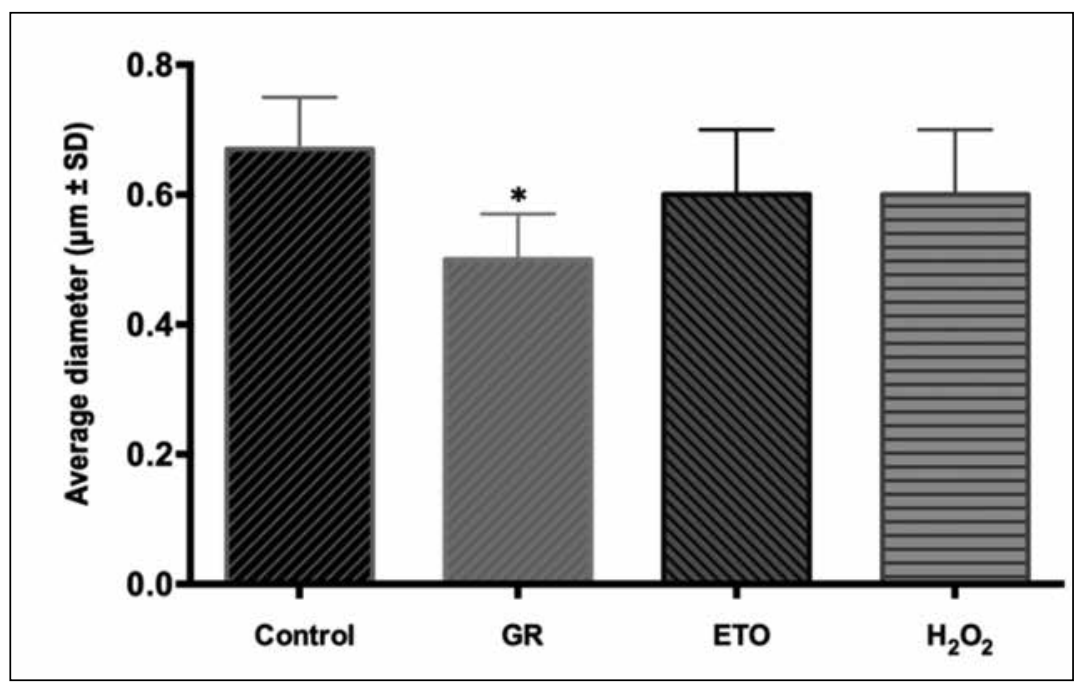

Figure 3. Graph corresponding to the percentage of the diameter of the fibers, the scaffolds sterilized by GR decreased the diameter of the fibers, having a statistically significant difference (asterisk).

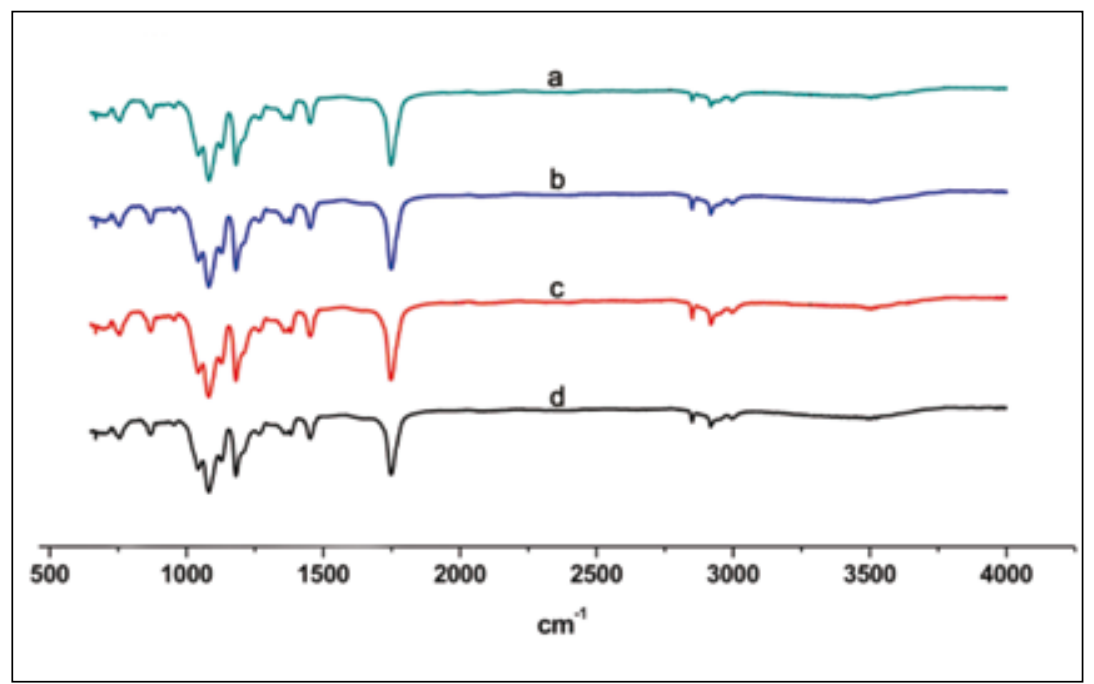

Figure 4. Characteristic FTIR spectrum of PLA scaffolds sterilized by a) $\mathrm{GR}, \mathrm{b}) \mathrm{H}_{2} \mathrm{O}_{2}$, c) ETO and d) control. $\mathrm{GR}=$ Gama radiation, ETO = Ethylene Oxide, $\mathrm{H}_{2} \mathrm{O}_{2}=$ Hydrogen Peroxide Based Plasma. 


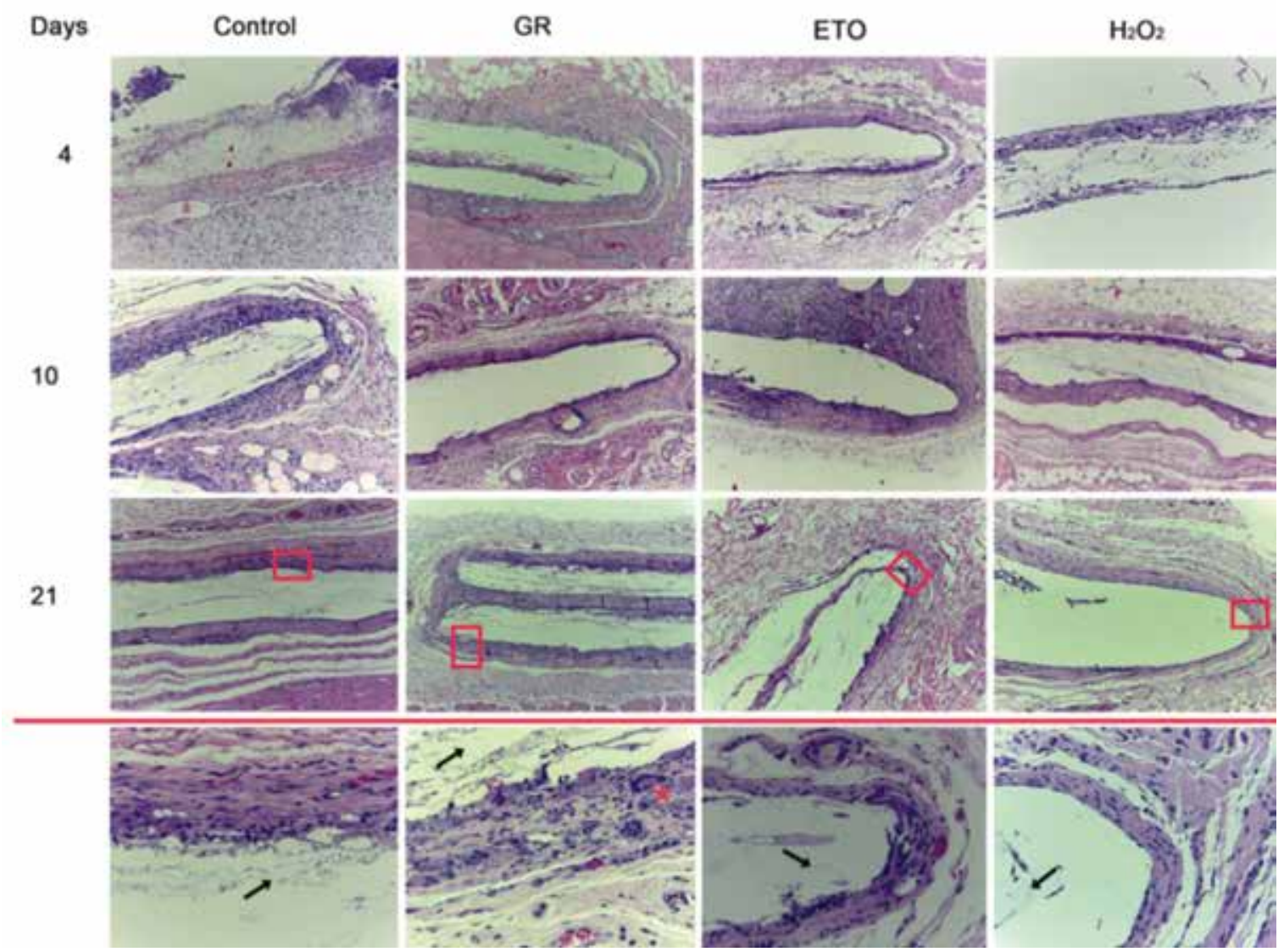

Figure 5. Photomicrographs stained with $\mathrm{H} \& \mathrm{E}(10 \mathrm{X})$ of histological sections of rat's subcutaneous cellular tissue, where the cellular response to the implantation of PLA scaffolds sterilized by different techniques can be compared at different periods of time. The lower panel corresponds to a 40X magnification of the upper boxes, where it can be seen that the PLA fibers are still present (arrows) the samples sterilized with GR show an incipient formation of giant cells (asterisk) the samples sterilized by $\mathrm{H}_{2} \mathrm{O}_{2}$ where There is no histological evidence of giant cells, and the wall shows scarce connective tissue in comparison to other groups. $\mathrm{GR}=$ Gama radiation, ETO $=$ Ethylene Oxide, $\mathrm{H}_{2} \mathrm{O}_{2}=$ Hydrogen Peroxide Based Plasma.

\section{DISCUSSION}

All biomaterials used for direct interaction with biological tissues must comply with certain physiochemical and biological properties $(17,18)$, because they must serve not only to physically support to the cells, but also have to provide the necessary chemical and biological substances to guide cell adhesion, proliferation, differentiation, and organization (18). However, biomaterials should also be efficiently sterilized, i.e. scaffolds designed for tissue regeneration should be free of bacteria, fungi and/or viruses. Scaffolds must have a terminal sterilization strategy, that at the same times allows to maintain their physical and chemical properties, since undesirable changes to the characteristics of the biomaterial may affect cell-material interactions, and also, it could cause unfavorable reactions in the tissues.

Currently there are a large number of terminal sterilization techniques for thermosensitive biomaterials, such as the PLA. In the present study only three sterilization techniques were used for their evaluation: ETO, GR, $\mathrm{H}_{2} \mathrm{O}_{2}$ based plasma, and were compare with a scaffold that was only disinfected with $70 \%$ ethanol. In the case of biomaterials used for tissue regeneration, the 
surface structure is very important, fibers could mimic the structure of the extracellular matrix providing support for cell growth.

Rediguieri et al. (19) have reported that sterilization such as ETO and GR techniques cause minimal structural damage to PLA scaffolds. In the present study, scaffolds sterilized by ETO showed accumulation of spheroid structures that formed clumps over the surface of the fibers, however, the distribution and diameter of the fibers were similar to the control. The results contradict the findings of Valente et al. (20), they reported that sterilization with ETO caused changes in the orientation of fibers from the scaffolds. The authors mentioned that such changes were the result of a modification in the surface structure morphology, probably due to the effect of pressure and temperature generated inside the gas chamber of ethylene oxide, which is similar to the glass transition temperature of the PLA. The temperature inside the gas chamber could promoted the formation of clusters in the surface structure of the scaffold, however, modifications on the diameter of the fibers are not significant.

In the case of the scaffolds sterilized by $\mathrm{GR}$, the diameter of the fibers was modified, it decreased in sized with respect to the control. It has been proposed by Gorna et al. that the formation of free radicals and probable a cross-linking of the fibers are generated by gamma irradiation (21, 22), together with a possible reduction in tension and in the module could cause reduction of the fibers (23).

For the samples sterilized with $\mathrm{H}_{2} \mathrm{O}_{2}$, the morphology and porosity of the fibers was conserved, which was considered a great advantage over other sterilization techniques. However, in the study made by Dai et al. (24) $\mathrm{H}_{2} \mathrm{O}_{2}$ sterilization decreased the molecular weight and tensile strength of the PLA scaffolds and increased their degradation rate. Further studies to evaluate the degradation rate of
PLA scaffolds in vivo and compare such rate with the rate of regeneration of the tissues of interest are needed.

To determine if the different sterilization techniques modify the chemical composition of the material, the scaffolds of PAL were analyzed by FTIR. Neither of the conditions modified the chemical structure of the scaffolds, being the spectra equal to that of the control group. The results of the present study confirmed that 7\% PLA scaffolds are only modified in a physical way by the sterilization procedures used, which represent advantage for in vivo used of the scaffolds. Probably, the biological properties of the scaffolds are not modified by common sterilization methods, however, more studies on the sterilization of biomaterials are needed.

Preclinical testing using small animal models of subcutaneous implantation are widely use to evaluate the tissue immune reaction and recellularization. Rat subcutaneous implants enables to asses tissue compatibility, such as, irritation, biodegradation, sensitivity reactions, etc. (25). The present study, evaluate the subcutaneous cellular tissue of Wistar rats after the implantation of $7 \%$ of PLA scaffolds, at three different times (4, 10 and 21 days). The results of the present study showed that all scaffolds sterilized with different methods triggered an initial inflammatory response, which decreased with over time. Interestingly, samples sterilized by GR showed a more specific reaction response, and numerous giant cells were found in the tissue. Probably the modification of the scaffold's surface structure, due to the amount of gamma radiation ( $25 \mathrm{KGy}$ ) is accompanied by the formation of free radicals through the cleavage of the hemolytic bond.

Bosworth et al. (26) explained that cleavage of the hemolytic bond occurs as a result of the sources of $60 \mathrm{Co}$. The authors used photon 
energies of 1.17 and $1.33 \mathrm{MeV}$, which correspond to 5 orders of magnitude greater than the average energy of a chemical bond. Probably the energy of the chemical bonds is responsible for a more severe inflammatory response in the GR sterilized samples. It is important to mention that, the FTIR analysis showed that the ETO-sterilized PLA scaffolds were free of ethylene oxide, due to good aeration by the equipment (12 hours).

The samples sterilized by $\mathrm{H} 2 \mathrm{O} 2$ and control did not show an unfavorable reaction in the subcutaneous tissue model. In this respect, disinfection in $70 \%$ ethanol serves as a useful control because the morphology and the molecular weight of the polymer are not affected by the ethanol treatment, however, ethanol is an unsuitable sterilization method because it does not adequately eliminate hydrophilic viruses and bacterial spore (27).

It should be mentioned that based on the histological response, the PLA 7\% scaffolds are biocompatible in Wistar rat subcutaneous cellular tissue, and they should be evaluated at a longer times to get a deeper understanding of the regeneration process.

\section{CONCLUSION}

The results obtained by the physicochemical and morphological characterization and at in vivo analysis in the present study suggest that $\mathrm{H}_{2} \mathrm{O}_{2}$ sterilization could be the best strategy for sterilization of $7 \%$ of PLA scaffolds synthesized by air jet spinning. PLA scaffolds sterilized by $\mathrm{H}_{2} \mathrm{O}_{2}$ maintain their chemical composition and the surface structure after the procedure. Moreover, PLA $\mathrm{H}_{2} \mathrm{O}_{2}$ sterilized scaffolds showed a favorable tissue respond in the histological evaluation of a subcutaneous implantation model in vivo. The results of the present study showed that plasma sterilization of hydrogen peroxide is the best method to sterilize PLA scaffolds, compare to GR and ETO techniques.

\section{ACKNOWLEDGMENTS}

Authors want to thank to Enrique Pinzón Estrada and Ismael Torres Saldaña for technical assistance with laboratory animals, as well as to thank to the financially support by funds from DGAPAUNAM: PAPIIT IA205818 and IT203618 projects and for CONACYT No. A1-S-9178 project.

\section{REFERENCE}

1. Rosales Ibáñez R., Alvarado Estrada K. N., Ojeda Gutiérrez F. Ingeniería Tisular en Odontología. Rev Adm. 2012;VOL. LXIX (4): 164-7.

2. Hernández Figueroa C. Obtención de andamios de colágeno para la restauración del tejido del miocardio. 2016; VII (3): 15-24.

3. Estrada Catalina, Paz Ana Cristina LLE. Ingeniería de tejido óseo: Consideraciones básicas. Rev EIA. 2006; 5: 93-100.

4. German F., Atala A. Reconstrucción de tejidos y órganos utilizando ingeniería tisular. Arch argent pediatr. 2000; 98 (2): 103-15.

5. Ribeiro L., Castro E., Ferreira M., Helena D., Robles R., Faria e Almeida A, et al. Conceptos y aplicaciones de la ingeniería tisular en Otorrinolaringología. Acta Otorrinolaringológica Española. 2015; 66 (1): 43-8.

6. Fabres V. C. Técnicas del futuro: ingeniería de tejidos y uso de células madre en medicina reproductiva. Rev Médica Clínica Las Condes. 2010; 21 (3): 488-93.

7. Yoganarasimha S., Trahan W. R., Best A. M., Bowlin G. L., Kitten T. O., Moon P. C., et al. PeraceticAcid:APracticalAgent forSterilizing Heat-Labile Polymeric Tissue-Engineering Scaffolds. Tissue Eng Part C Methods [Internet]. 
2014; 20 (9): 714-23. Available from: http:// online.liebertpub.com/doi/full/10.1089/ten. tec.2013.0624\%5Cnhttp://online.liebertpub. com/doi/abs/10.1089/ten.tec.2013.0624

8. Ochoa S, Aguilar N, Méndez A. Investigación y Ciencia. Ing tejidos Una nueva Discip en Med Regen [Internet]. 2012;64:61-9. Available from: http://www.investigacionyciencia.es/ revistas/investigacion-y-ciencia/numero/429/ el-futuro-de-la-energa-elica-8652

9. Ibarra C., Garciadiego D., Martínez V., Velasquillo C. Ingeniería de tejidos y osteoartritis. Reumatol Clínica [Internet]. 2007;3(Supplement 3):S19-22. Available from: http://www.sciencedirect.com/science/ article/pii/S1699258X07736501

10. Sequeda L. G., Díaz J. M., Gutiérrez S. J., Perdomo S. J., Gómez O. L. Obtención de hidroxiapatita sintética por tres métodos diferentes y su caracterización para ser utilizada como sustituto óseo. Rev Colomb Ciencias Químico-Farmacéuticas. 2012; 41 (1): 50-66.

11. MacNeil S. Progress and opportunities for tissue-engineered skin. Nature [Internet]. 2007; 445 (7130): 874-80. Available from: http://www.nature.com/doifinder/10.1038/ nature05664\%5Cnhttp://www.ncbi.nlm.nih. gov/pubmed/17314974

12. Rezwan K., Chen Q. Z., Blaker J. J. R. B. Biodegradable and bioactive porous polymer/ inorganic composite scaffolds for bone tissue engineering. Biomaterials. 2006; 27: 3413-31.

13. Zhang L., Webster T. J. Nanotechnology and nanomaterials: Promises for improved tissue regeneration. Nano Today. 2009; 4 (1): 66-80.

14. Beltrán F., Pérez E., Cerrada M. L., de la Orden M. U., Martínez-Urreaga J. Caracterización por espectroscopía IR de cambios estructurales del poli(ácido láctico) en presencia de agua. efecto de la incorporación de arcillas. Avances en Materiales Poliméricos. XIV Reunión del
Grupo Especializado de Polímeros (GEP) de la RSEQ y RSEF". 2016. 87-88 p.

15. Jiménez P., Sibaja M., Vega-Baudrit J. Síntesis y caracterización de Poli(Ácido L-Láctico) por policondensación directa, obetenido del fermento de deshechos agroindustriales de banano (Musa acuminata AAA variedad Cavendish cultivar Gran naine) en Costa Rica. Rev Oberoamericana Polímeros. 2012; 13 (2): 52-9.

16. Suarez-Franco J. L., Vázquez-Vázquez F. C., Pozos-Guillen A. M. J., Alvarez-Fregoso $\mathrm{O}$ A-PM. Influence of diameter of fiber membrane scaffolds on the biocompatibility of hPDL mesenchymal stromal cells. Dent Mater J. 8;37 (3): 465-73.

17. Colorado A. C., Agudelo C. A., Moncada A. M. E. Análisis de Biomateriales para uso en ingeniería de tejidos de piel. Rev ing biomed. 2013; 7: 11-23.

18. Chachques J. C., Herreros J., Trainini J. C., Lago N., Díez Solórzano L., Tascón V., et al. Ingeniería tisular y miocardio bioartificial. Cirugía Cardiovasc [Internet]. 2011; 18 (3): 217-24. Available from: http://linkinghub. elsevier.com/retrieve/pii/S1134009611700572

19. Rediguieri F., Corte R., Dua K., Satiko I., Terezinha De J., Pinto A. Impact of sterilization methods on electrospun scaffolds for tissue engineering. Eur Polym J [Internet]. 2016; 82: 181-95. Available from: http:// dx.doi.org/10.1016/j.eurpolymj.2016.07.016

20. Valente T. A. M., Silva D. M., Gomes P. S., Fernandes M. H., Santos J. D., Sencadas V. Effect of sterilization methods on electrospun poly (lactic acid) (PLA) fiber alignment for biomedical applications. ACS Appl Mater Interfaces. 2016; 8 (5): 3241-9.

21. LooJ.S.C.,OoiC.P.,BoeyF.Y.C.Degradation of poly(lactide-co-glycolide) (PLGA) and poly(l-lactide) (PLLA) by electron beam 
radiation. Biomaterials [Internet]. 2005 Apr [cited 2017 Jul 19]; 26 (12): 1359-67. Available from: http://linkinghub.elsevier. com/retrieve/pii/S0142961204004429

22. Cottam E., Hukins D. W. L., Lee K., Hewitt C., Jenkins M. J., Wallace W. A., et al. Effect of sterilisation by gamma irradiation on the ability of polycaprolactone (PCL) to act as a scaffold material. Med Eng Phys [Internet]. 2009 Mar 1 [cited 2017 Jul 20]; 31 (2): 2216. Available from: http://www.ncbi.nlm.nih. gov/pubmed/18760952

23. Gorna K., Gogolewski S. The effect of gamma radiation on molecular stability and mechanical properties of biodegradable polyurethanes for medical applications. Polym Degrad Stab. 2003; 79 (3): 465-74.

24. Dai Z., Ronholm J., Tian Y., Sethi B., Cao X. Sterilization techniques for biodegradable scaffolds in tissue engineering applications. J Tissue Eng
[Internet]. 2016;7:204173141664881. Available from: http://journals.sagepub.com/ doi/10.1177/2041731416648810

25. Broon N. J., Martínez M. P., Ramírez M. L., Tinajero M. C., Lagunas Á. L., Bramante C. M. Respuesta inflamatoria de Bioceramic a la implantación de tubos de dentina en tejido sucutáneo de ratas. Rev Odonto Mex. 2016; 20 (3):174-8.

26. Bosworth L. A., Gibb A., Downes S. Gamma irradiation of electrospun poly( $\varepsilon$-caprolactone) fibers affects material properties but not cell response. J Polym Sci Part B Polym Phys. 2012; 50 (12): 870-6.

27. Holy C. E., Cheng C., Davies J. E., Shoichet M. S. Optimizing the sterilization of PLGA scaffolds for use in tissue engineering. Biomaterials [Internet]. 2000 Jan [cited 2017 Jul 19]; 22 (1): 25-31. Available from: http://linkinghub.elsevier.com/retrieve/pii/ S0142961200001368 